\title{
Impact of the Clean Development Mechanism on wind energy investments in Turkey
}

\author{
Murat Tunç and Ruhan Pak
}

\begin{abstract}
Background: As carbon trading continues to be implemented on both a national and an international scale, it is becoming an important factor in renewable energy investment decisions. Turkey, with continuous growth of carbon dioxide emission and energy consumption since 2001, ratified the Kyoto Protocol in 2009 and began registration of projects with greenhouse gas reductions in 2010. In light of these developments, wind energy resources with a potential of 48,000 MW are among the most efficient and effective solutions for clean and sustainable energy in Turkey. The aim of our study is to reveal the importance of the Clean Development Mechanism (CDM) of the Kyoto Protocol on wind energy investment decisions.
\end{abstract}

Methods: A broad review of wind energy in Turkey is given, and then, a comprehensive feasibility study of a wind energy firm with a valuation model including Certified Emission Reduction (CER) prices is applied to a case study, the Mega Metallurgy Power. With a holistic and interdisciplinary system engineering approach, results are obtained using comprehensive analysis of technology, emission, and power generation of a wind energy firm linked to a valuation model.

Results: This comprehensive model sets the investment decision-making criteria, the enterprise value comparison with total financing. Finally, a sensitivity analysis is run to show that the enterprise value is positively correlated with CER prices.

Conclusions: Based on these results, it is concluded that if the world's largest carbon offsetting program, the CDM, prevails after 2012, CER prices will have a positive impact on wind energy firm valuations and related investment decisions.

Keywords: Wind energy, Clean development mechanism, Valuation

\section{Background}

\section{Clean development mechanism}

In 2005, the Kyoto Protocol went into effect. It required a strong binding commitment from developed countries to reduce their greenhouse gas emissions from initial emission levels in 1990 to individually assigned levels through the first 5-year commitment period, 2008 to 2012. The Kyoto Protocol provides three flexible mechanisms to help reduce the costs of achieving these emission reduction targets - Emissions Trading, Joint Implementation, and the Clean Development Mechanism (CDM). These mechanisms enable the signatory countries to purchase emission credits from countries that bear

\footnotetext{
* Correspondence: ruhan@pak.web.tr

Systems Engineering Department, Engineering Faculty, Yeditepe University, Kayisdagi Cad, Istanbul 34755, Turkey
}

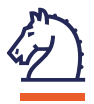

lower greenhouse gas reduction costs, without reducing greenhouse gas emissions domestically. The appeal of carbon trading is gaining efficiency by lowering the cost of climate mitigation, which can be accomplished by allowing the market to find the least expensive sources of reduction. CDM is the first and only setup that allows developing countries to participate in reducing greenhouse gases under the United Nations Framework Convention on Climate Change (UNFCCC). The use of offsets is controversial and has limits. Offset usage in trading schemes is usually limited to a proportion of the overall emission target. This limitation ensures that emitters substantially control their own emissions and do not just buy their way out of their obligations. CDM basically relies on three conditions to work: accurate measurement of existing and future emissions, all nations committing 
to emission reduction targets, and proper verification of carbon offset projects. The CDM and European Union Emissions Trading Scheme (EU ETS) are as yet the only two substantial, legally binding carbon markets in full operation. The EU ETS is the only major scheme of its type in operation, although others are under consideration in the USA, Canada, and Australia. New Zealand began a transitional phase of its ETS in 2010. The EU ETS has completed its trial phase and has begun a second phase concurrent with the Kyoto commitment period. Around 1.3 billion tons of emission savings are expected by the end of that period in 2012. Savings are monitored and verified according to rules set by the United Nations [1].

On the other hand, voluntary markets that mainly deal in offsets attract criticism for lack of verification of actual emission cuts. These markets cater to companies, organizations, and individuals who decide of their own accord to offset their emissions. Because voluntary markets are not part of a compulsory scheme imposed by governments, generally, no authority regulates standards for projects generating carbon offset credits. It is clear that in some recent cases, firms offering carbon credits have accepted money for credits for dubious emission reductions. However, reputable international accreditation schemes backed by international aid groups and environmental organizations have raised the bar in the voluntary market since 2007. Voluntary buyers of offset credits should only consider credits from projects approved by one or more of the carbon offset standards, such as the Gold Standard and Voluntary Carbon Standard. These provide independent thirdparty verification of emission reductions. By 2008, 96\% of offset projects were registered with one or more of these independent standards [2]. In 2009, the global carbon market grew to $\$ 144$ billion, which has gone up 6\% from 2008 despite enduring its most challenging year to date. The voluntary market, which is restricted to $0.2 \%$ of the global market, grew to $\$ 338$ million [3].

A new international framework is still under negotiation and must be established to ensure continuing efforts to reduce global greenhouse gases. To date, however, no solid and tangible agreement has emerged on which to build a post 2012 framework. The recent Copenhagen Accord of 2009 failed to lead to a specific international mechanism to replace the CDM. It seems likely that the CDM - possibly with minor reform - will be part of any new agreement.

\section{Turkey's energy outlook}

Turkey's demand for energy and electricity is increasing rapidly. It is heavily dependent on expensive imported energy resources that burden the economy. The most important renewable resources are hydropower, biomass, geothermal, solar, and wind. Turkey's geographic location has several advantages for extensive use of most of these renewable energy sources. Its hydroelectric potential can meet $33 \%$ to $46 \%$ of its electric energy demand in 2020 . Between 2000 and 2009, power and energy demand in the country have grown at average rates of $4.7 \%$ and $5.1 \%$, respectively. Turkey's average annual growth in both power (Figure 1) and energy (Figure 2) demands between 2010 and 2019 is projected to be $7.2 \%$.

Under this scenario, according to the Republic of Turkey Ministry of Energy and Natural Resources, beginning in 2018 at the latest, there will be a supply shortage. This will be so even if the 13,762-MW private and 3,475-MW public projects under construction after 2009 are completed. From 2002 to 2009, natural gas, coal, and hydro resources have been utilized at a growing rate. According to the Energy Market Regulatory Authority, from 2010 to 2015, capacity utilization of these resources will continue to grow. For the same period, a significant power capacity increase is expected for wind, but not for lignite [4].

Regulation, technology, and the political outlook have mainly accounted for environmental and energy policy outcomes in Turkey. The energy policies set by successive governments were highly sensitive to international forces and dynamics. These policies have consistently underplayed the importance of renewable energy and have instead focused on hydropower and nuclear power, despite nationwide protests. In absolute figures, greenhouse gas emissions in Turkey do not seem alarming. However, energy-related carbon emissions have been growing much faster than the economy, at a rate of $6 \%$ annually since 1990, and the carbon intensity of the economy is higher than that of developed countries. Therefore, it is inevitable that carbon emissions of Turkey are considered in foreign policy. After ratifying both the UNFCCC in 2004 with differences from Annex I countries in 2001 and the Kyoto Protocol of the Convention in 2009 with Annex I country status, Turkey has become eligible for trading carbon credits under the provisions of the CDM. Core principles of the UNFCCC include that of protecting the climate on an equal basis

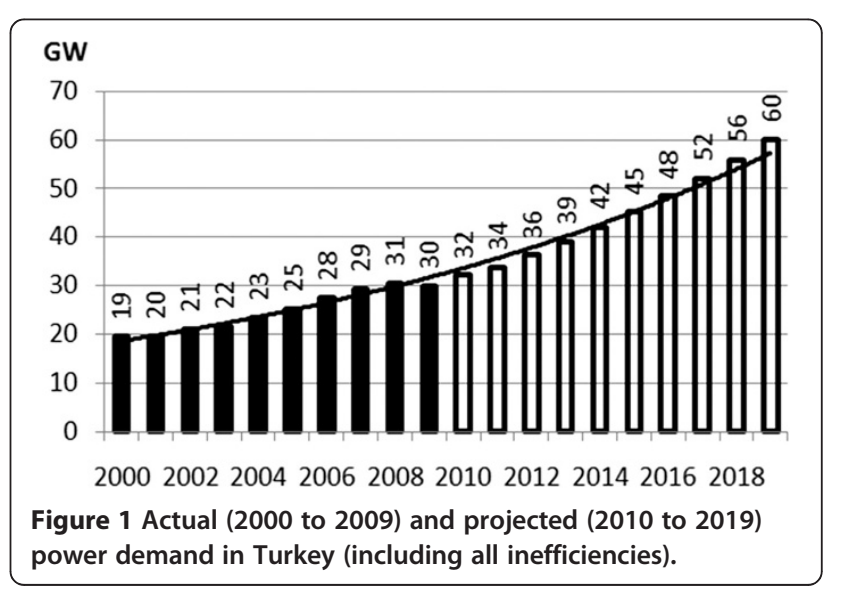




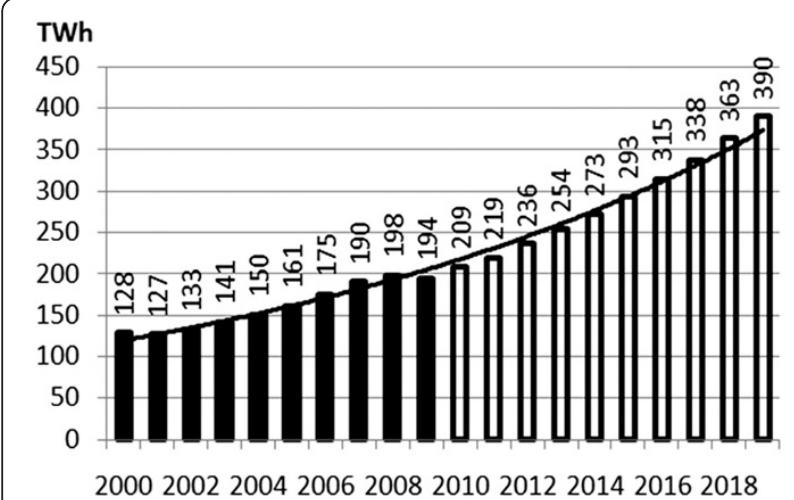

Figure 2 Actual (2000 to 2009) and projected (2010 to 2019) energy demand in Turkey.

and with joint effort but different responsibilities. These principles consider needs and specific conditions of developing countries affected by climate change and take effective measures with minimum cost to prevent climate change. Moreover, these principles encourage sustainable development by integrating policies and measures within national development plans. By 2012, Turkey will implement clean development goals to develop institutional capacities and information systems that comply with the provisions of the Convention on an

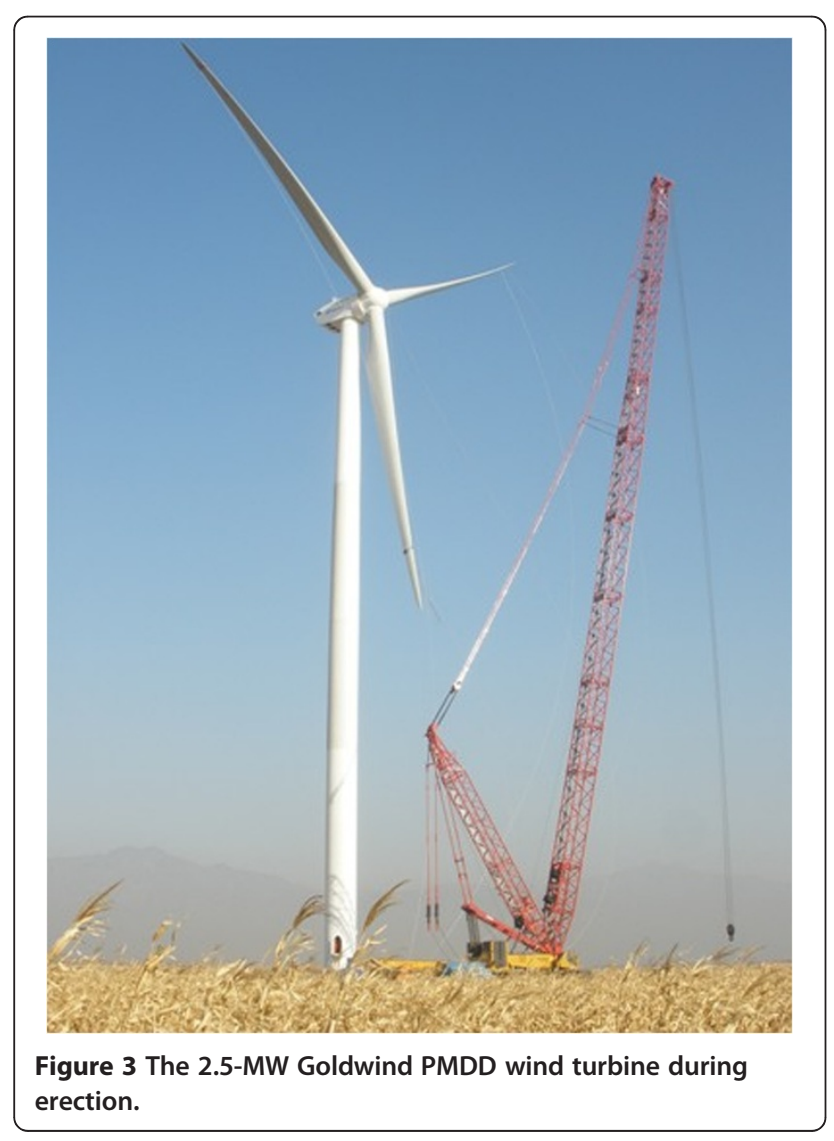

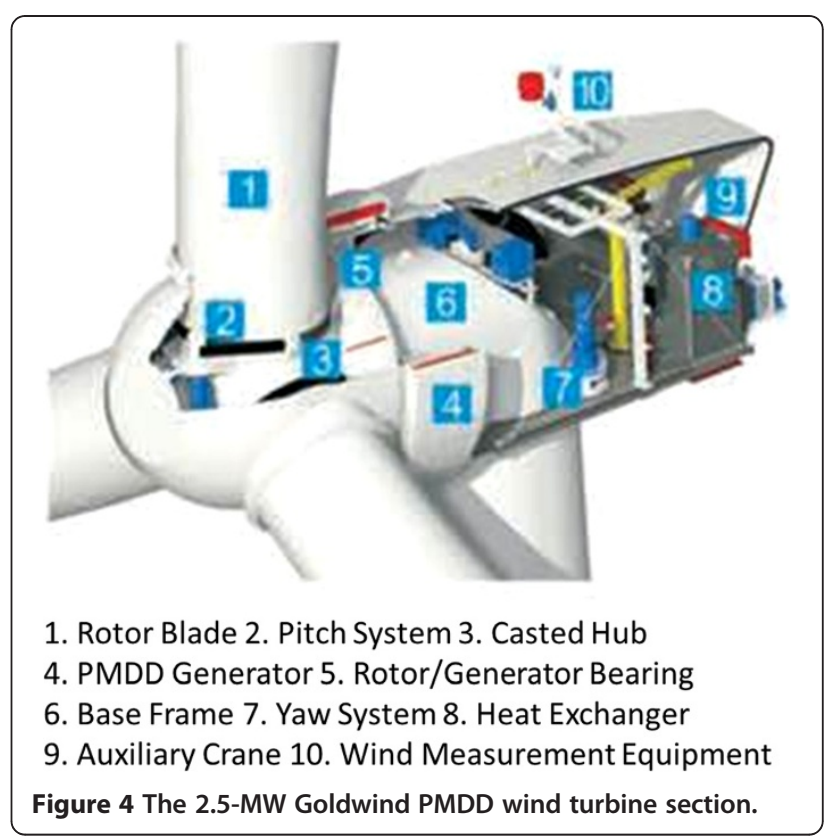

equitable basis. Unlike domestic energy procurement strategies, the global warming dimension of energy politics receives scant attention from civil society and environmental/nongovernmental organizations. A number of promising steps have been taken, such as the Electricity Market Act and Natural Gas Market Law of 2001, toward creating more private involvement and competition. Energy development in Turkey has been dominated by public investment and management. Turkey has made extensive use of financing models such as build-own-operate and build-own-transfer for liberalization, restructuring, and privatization of the energy sector. Although there is steady increase in the use of renewable energy sources, it is still inadequate. Therefore, Turkey needs to focus on governmental grants, feed-in tariffs, and renewable energy certificates [5].

Furthermore, from production to energy use, Turkey needs to increase energy efficiency, prevent waste, and diversify energy supply so that risks associated with a

Table 1 Technical specifications of Goldwind's 2.5-MW turbine

\begin{tabular}{ll}
\hline Specification & Value \\
\hline Rated power $(\mathrm{KW})$ & 2,500 \\
Rotor diameter $(\mathrm{m})$ & 100 \\
Swept area $\left(\mathrm{m}^{2}\right)$ & 7,854 \\
Cut-in wind speed $(\mathrm{m} / \mathrm{s})$ & 3 \\
Cut-out wind speed $(\mathrm{m} / \mathrm{s})$ & 20 \\
Hub height $(\mathrm{m})$ & 80 \\
Power coefficient $\left(C_{\mathrm{p}}\right)$ & 0.47 \\
Number of blades & 3 \\
\hline
\end{tabular}


Table 2 Turbine coordinates

\begin{tabular}{lll}
\hline Coordinates (N) & Coordinates (W) & Altitude $(\mathrm{m})$ \\
\hline $36^{\circ} 28157^{\prime \prime}$ & $36^{\circ} 12137^{\prime \prime}$ & 678 \\
$36^{\circ} 28144^{\prime \prime}$ & $26^{\circ} 12132^{\prime \prime}$ & 806 \\
$36^{\circ} 28139^{\prime \prime}$ & $36^{\circ} 13 / 03^{\prime \prime}$ & 761 \\
$36^{\circ} 28134^{\prime \prime}$ & $36^{\circ} 12138^{\prime \prime}$ & 810 \\
$36^{\circ} 28159^{\prime \prime}$ & $36^{\circ} 13 / 02^{\prime \prime}$ & 745 \\
\hline
\end{tabular}

$73 \%$ imported energy supply can be mitigated. The country is estimated to have an energy-saving potential of $30 \%$ in the construction industry, $20 \%$ in the production industry, and $15 \%$ in the transportation industry. The Energy Efficiency Law of 2007 and Regulation on Increasing Efficiency in the Use of Energy Sources and Energy of 2008 were enacted to eliminate these inefficiencies. In the course of Turkey's EU accession process, new power generation plants were built in compliance with the Environmental Impact Assessment Regulation and Regulation on Protection of Air Quality from industrial plants, and emission readings from power plants are regularly checked. Reducing electricity generation, transmission, and distribution losses will help reduce emissions. Transmission losses are about $2.5 \%$ to $3 \%$, which is within world standards. On the other hand, distribution losses are high. The government aims to reduce losses by privatizing electricity distribution activities. The average ratio of lost and illegally consumed electricity within the distribution system in Organisation for Economic Co-operation and Development (OECD) countries is $4 \%$. This percentage is $6 \%$ in the world and around $15 \%$ in Turkey. Because it produces more than

Table 3 Wind velocity measurements $(\mathrm{m} / \mathrm{s})$

\begin{tabular}{llllllll}
\hline Month & \multicolumn{7}{c}{ Years } \\
\cline { 2 - 8 } & $\mathbf{2 0 0 4}$ & $\mathbf{2 0 0 5}$ & $\mathbf{2 0 0 6}$ & $\mathbf{2 0 0 7}$ & $\mathbf{2 0 0 8}$ & $\mathbf{2 0 0 9}$ & Mean \\
\hline January & 6.91 & 6.81 & 6.91 & 6.70 & 6.86 & 7.02 & 6.87 \\
February & 6.89 & 6.91 & 6.96 & 6.36 & 6.62 & 6.88 & 6.77 \\
March & 6.71 & 6.50 & 6.13 & 6.25 & 6.26 & 6.53 & 6.40 \\
April & 5.60 & 6.26 & 6.00 & 6.39 & 6.69 & 3.85 & 5.80 \\
May & 5.67 & 5.95 & 5.42 & 5.63 & 5.37 & 6.99 & 5.84 \\
June & 5.60 & 5.76 & 6.08 & 6.26 & 6.65 & 6.57 & 6.15 \\
July & 6.51 & 6.83 & 4.81 & 6.62 & 6.31 & 6.13 & 6.20 \\
August & 6.00 & 6.79 & 6.16 & 6.20 & 6.17 & 6.01 & 6.22 \\
September & 6.75 & 6.68 & 6.49 & 6.30 & 6.16 & 6.36 & 6.46 \\
October & 7.58 & 6.61 & 6.37 & 6.95 & 6.82 & 6.68 & 6.84 \\
November & 6.81 & 6.97 & 7.03 & 6.90 & 6.60 & 7.01 & 6.89 \\
December & 7.76 & 7.03 & 7.58 & 7.21 & 7.68 & 7.67 & 7.49 \\
Mean & 6.57 & 6.59 & 6.33 & 6.48 & 6.52 & 6.48 & 6.49 \\
\hline
\end{tabular}

$80 \%$ of global greenhouse gas emissions, the energy sector is key to accomplishing climate change policies [6].

\section{Wind energy in Turkey}

A rapid increase in the utilization of wind energy within the past 15 years was made possible to a large extent by technological developments and a favorable political climate. Since there have been continued improvements in the efficiency and economic competitiveness of wind energy systems, political aspects are now becoming more important. Among them are integration into the national and international power grid, integration into the international energy economy, and societal consensus concerning energy policy. Power generation from wind energy is thus in transition from an alternative to mainstream energy source. Wind can make a decisive future contribution to a climate-compatible and economically feasible power generation system [7]. Among renewable power plants, wind has the major advantage of quick installation, and the disadvantages of supply-demand mismatch, critical efficiency parameters (wind, turbine, and topography), grid integration of dispersed and intermittent wind generation, and noise [8]. The global annual wind resource energy and total installed wind energy power are estimated at $53 \mathrm{TW} h$ and 40,301 MW, respectively. One-third of the latter figure is in Germany. The investment necessary for reaching the world wind energy target of 1,245 GW by 2020 is $\$ 900$ billion. By then, production costs are expected to decrease from 4.93 to 3.19 cents/kW h (USD) as the annual global business volume in wind turbines increases from $\$ 10.4$ billion to $\$ 104$ billion.

According to the Turkish Wind Energy Potential Atlas developed in 2007, the country has a minimum wind energy potential of 5,000 MW in regions with annual wind speeds of $8.5 \mathrm{~m} / \mathrm{s}$ and higher, and 48,000 MW in areas with speeds higher than $7.0 \mathrm{~m} / \mathrm{s}$. There has been some progress in increasing the amount of installed wind energy power, which was only $18 \mathrm{MW}$ as of 2004. By the end of 2009, this figure reached 802.8 MW. Upon enactment of the Renewable Energy Law, licenses were granted to 93 new wind projects that deliver a total installed power of 3,363 MW. Out of these projects, 1,100 MW were under construction in 2010 [6]. The Renewable Energy Law of 2005 also introduced the government's purchasing guarantee for electricity procured from renewable resources and hence paved the way for wind energy investments. Within the same framework, sales of renewable energy in the free market were defined. Besides such legal arrangements, the government still needs to have the transmission system ameliorated, bureaucratic studies coordinated, and incentives for promoting wind energy resolved. On the other hand, all wind power plants are owned by investors from the 


\begin{tabular}{|c|c|c|c|c|c|c|c|c|c|c|c|c|c|c|c|c|c|c|c|c|c|c|c|c|}
\hline & \multicolumn{24}{|c|}{ Hour } \\
\hline & 1 & 2 & 3 & 4 & 5 & 6 & 7 & 8 & 9 & 10 & 11 & 12 & 13 & 14 & 15 & 16 & 17 & 18 & 19 & 20 & 21 & 22 & 23 & 24 \\
\hline Velocity $(\mathrm{m} / \mathrm{s})$ & 3.3 & 3.8 & 4.2 & 3.3 & 2.8 & 3.0 & 4.0 & 2.7 & 5.2 & 6.7 & 6.8 & 6.8 & 5.7 & 8.3 & 9.2 & 9.3 & 6.5 & 4.2 & 4.3 & 3.7 & 4.0 & 2.8 & 3.7 & 3.3 \\
\hline
\end{tabular}

private sector, and these investors need to focus more on complying with grid connection criteria.

When the distribution of wind potential by geographic regions is evaluated, wind speed is generally found to be 6.0 to $7.0 \mathrm{~m} / \mathrm{s}$ on the Marmara, western Black Sea, and eastern Mediterranean coasts; 5.0 to $6.0 \mathrm{~m} / \mathrm{s}$ on the western Mediterranean coasts; 7.0 to $8.5 \mathrm{~m} / \mathrm{s}$ on the north western Aegean coasts; and 4.5 to $5.5 \mathrm{~m} / \mathrm{s}$ in interior regions [9].

Eventually, firms willing to exploit this considerable wind energy potential must take carbon trading into consideration in their investment decisions [10]. This development raises a question: what will be the impact of the CDM on valuations of wind energy firms?

\section{Methods}

\section{Case study: mega metallurgy power}

To demonstrate the impact of the CDM on valuations of wind energy firms, we investigate a case study, Mega Metallurgy Power. There is no prior study that links a comprehensive analysis of technology, emission, and power generation of a wind energy firm with a valuation model that includes Certified Emission Reduction (CER) prices.

Mega Metallurgy is a steel production firm in the Payas Organized Industrial Zone/Hatay, with an annual capacity of 50,000 tons. Mega Metallurgy seeks permanent solutions, such as a wind energy project in Hatay, instead of temporary ones, like building a de-dusting plant to decrease its air pollution. Establishing a wind energy firm (Mega Metallurgy Power) may enable Mega Metallurgy to offset its own air pollution, averting the need for CER purchases or the probable incurrence of EU penalties after 2012. To make this investment decision, a valuation model including the CDM, along with analysis of CER prices on valuations, is required.

Technology analysis is carried out to determine the most eligible wind turbine at the time of investment to benefit from the continuous progress in wind energy systems. Once the wind turbines are selected, the emission analysis is conducted to find annual allowed $\mathrm{CO}_{2}$ emissions. The power analysis is next, with which the required number of turbines and their installed power capacity and $\mathrm{CO}_{2}$ emission savings are calculated, according to the selected wind turbines and annual allowed $\mathrm{CO}_{2}$ emissions. Power generation and $\mathrm{CO}_{2}$ emission saving data are fed into the financial analysis, from which the Mega Metallurgy Power enterprise value is derived, taking the CDM into account. This comprehensive model sets the investment decision-making criteria, which is the enterprise value comparison with total financing. Finally, a sensitivity analysis is run to conclude the positive correlation between the CER price and enterprise value.

With a holistic and interdisciplinary system engineering approach, the initial groundwork for systematic analysis of wind energy investments in Turkey and abroad, wherever the CDM is in effect, is laid in this study.

\section{Results and discussion}

\section{Technology analysis}

Wind turbine manufacturers are turning away from industry standard gearboxes and generators, in a bid to boost reliability and reduce the cost of wind power. Siemens has begun selling a 3-MW turbine with a direct drive system that replaces the conventional high-speed generator with a low-speed one, which eliminates the need for a gearbox. Recently, General Electric (GE) announced an investment of $\$ 442$ million in manufacturing facilities to build its own 4-MW direct drive turbines for offshore wind farms. Siemens' plans hinge on a new design that reduces the weight of the system generator. In conventional wind turbines, the gearbox increases the speed of the wind-driven rotor several hundredfold, which radically reduces the size of the required generator. Direct drive generators operate at the same speed as the turbine blades and must therefore be much larger - over $4 \mathrm{~m}$ in diameter for Siemens' 3-MW turbines. Yet, Siemens claims that the turbine's entire nacelle weighs just 73 metric tons - 12 tons less than its less powerful, gear-driven 2.3-MW turbines. Much of the weight reduction comes from the use of permanent magnets in the generator's rotor - a setup that GE is also using. Conventional turbine generators use electromagnets - copper coils fed with electricity from the

Table 5 Daily wind velocity frequency distribution (Weibull distribution)

\begin{tabular}{lllllllllll}
\hline & \multicolumn{10}{c}{ Velocity (m/s) } \\
\cline { 2 - 11 } & $\mathbf{( 0 - 1 )}$ & $\mathbf{( 1 - 2 )}$ & $\mathbf{( 2 - 3 )}$ & $\mathbf{( 3 - 4 )}$ & $\mathbf{( 4 - 5 )}$ & $\mathbf{( 5 - 6 )}$ & $\mathbf{( 6 - 7 )}$ & $\mathbf{( 7 - 8 )}$ & $\mathbf{( 8 - 9 )}$ & $\mathbf{( 9 - 1 0 )}$ \\
\hline Frequency & $2 \%$ & $7 \%$ & $9 \%$ & $15 \%$ & $20 \%$ & $17 \%$ & $8 \%$ & $1 \%$ & $0 \%$ & $0 \%$ \\
\hline
\end{tabular}


Table 6 Monthly capacity factors

\begin{tabular}{|c|c|c|c|c|c|c|c|c|c|c|c|c|c|}
\hline & \multicolumn{13}{|c|}{ Months } \\
\hline & Jan & Feb & Mar & Apr & May & Jun & Jul & Aug & Sep & Oct & Nov & Dec & Mean \\
\hline Rates & $45 \%$ & $48 \%$ & $41 \%$ & $30 \%$ & $31 \%$ & $36 \%$ & $37 \%$ & $37 \%$ & $42 \%$ & $39 \%$ & $40 \%$ & $48 \%$ & $40 \%$ \\
\hline
\end{tabular}

generator itself. A 15-mm-thick segment of permanent magnets can generate the same magnetic field as a 10- to $15-\mathrm{cm}$ section of copper coils. Siemens further reduced the weight by inverting its generator design. Rather than a steel rotor covered with permanent magnets spinning inside a stationary doughnut-shaped stator, the Siemens rotor is a steel cylinder with permanent magnets on the inside, and this rotor spins around a column-like stator. Siemens erected a prototype of its machine in Brande, Denmark in December 2010 and plans to begin mass production in 2011. GE's technology, which it acquired with the purchase of the Norwegian turbine producer ScanWind in 2009, is being demonstrated at a test site in Norway. Commercialization of its 4-MW machine is slated for 2012. The direct drive system, with half as many parts as a conventional turbine and no gearbox, increases reliability. However, direct drive systems introduce one potential problem. There are ongoing concerns regarding future supply of the rare earth metals used to make permanent magnets [11]. The first 2.5-MW Goldwind permanent magnet direct drive (PMDD) prototype was installed in China in 2009, and full production was initiated in February 2010. In November 2010, Goldwind's Jiangsu Dafeng offshore turbine plant was founded. Upon completion, it will be the largest offshore wind power equipment manufacturing site in China and one of the largest in the world, with a production capacity of 300 turbines per year. Recently, Goldwind has also developed a 3-MW turbine that was successfully installed and that began trial operation in Dabancheng. During erection and its parts, the 2.5-MW Goldwind PMDD wind turbine is seen in Figures 3 and 4, respectively.

Mega Metallurgy selected Goldwind's 2.5-MW PMDD wind turbines not only because of their availability and previous installation successes in Turkey, but also because of their technical specifications (Table 1) and

Table 7 Mega metallurgy power long-term loan amortization schedule (in dollars)

\begin{tabular}{|c|c|c|c|c|c|c|c|c|c|}
\hline Drawdowns & Balance & Available line & Date & Days & Repayment & Interest & Fee expense & Cash flow & Period \\
\hline $39,200,000$ & $39,200,000$ & 0 & 01.01 .2012 & 0 & 0 & 0 & 588,000 & $-38,612,000$ & 0 \\
\hline 0 & $39,200,000$ & 0 & 30.06 .2012 & 181 & 0 & 591,267 & & 591,267 & 1 \\
\hline 0 & $37,136,842$ & $2,063,158$ & 31.12 .2012 & 184 & $2,063,158$ & 601,067 & & $2,664,225$ & 2 \\
\hline 0 & $35,073,684$ & $4,126,316$ & 30.06 .2013 & 181 & $2,063,158$ & 560,147 & & $2,623,305$ & 3 \\
\hline 0 & $33,010,526$ & $6,189,474$ & 31.12 .2013 & 184 & $2,063,158$ & 537,796 & & $2,600,954$ & 4 \\
\hline 0 & $30,947,368$ & $8,252,632$ & 30.06 .2014 & 181 & $2,063,158$ & 497,909 & & $2,561,067$ & 5 \\
\hline 0 & $28,884,211$ & $10,315,789$ & 31.12.2014 & 184 & $2,063,158$ & 474,526 & & $2,537,684$ & 6 \\
\hline 0 & $26,821,053$ & $12,378,947$ & 30.06 .2015 & 181 & $2,063,158$ & 435,670 & & $2,498,828$ & 7 \\
\hline 0 & $24,757,895$ & $14,442,105$ & 31.12.2015 & 184 & $2,063,158$ & 411,256 & & $2,474,414$ & 8 \\
\hline 0 & $22,694,737$ & $16,505,263$ & 30.06 .2016 & 182 & $2,063,158$ & 375,495 & & $2,438,653$ & 9 \\
\hline 0 & $20,631,579$ & $18,568,421$ & 31.12 .2016 & 184 & $2,063,158$ & 347,986 & & $2,411,144$ & 10 \\
\hline 0 & $18,568,421$ & $20,631,579$ & 30.06 .2017 & 181 & $2,063,158$ & 311,193 & & $2,374,351$ & 11 \\
\hline 0 & $16,505,263$ & $22,694,737$ & 31.12 .2017 & 184 & $2,063,158$ & 284,716 & & $2,347,874$ & 12 \\
\hline 0 & $14,442,105$ & $24,757,895$ & 30.06 .2018 & 181 & $2,063,158$ & 248,954 & & $2,312,112$ & 13 \\
\hline 0 & $12,378,947$ & $26,821,053$ & 31.12 .2018 & 184 & $2,063,158$ & 221,446 & & $2,284,604$ & 14 \\
\hline 0 & $10,315,789$ & $28,884,211$ & 30.06 .2019 & 181 & $2,063,158$ & 186,716 & & $2,249,874$ & 15 \\
\hline 0 & $8,252,632$ & $30,947,368$ & 31.12.2019 & 184 & $2,063,158$ & 158,175 & & $2,221,333$ & 16 \\
\hline 0 & $6,189,474$ & $33,010,526$ & 30.06 .2020 & 182 & $2,063,158$ & 125,165 & & $2,188,323$ & 17 \\
\hline 0 & $4,126,316$ & $35,073,684$ & 31.12 .2020 & 184 & $2,063,158$ & 94,905 & & $2,158,063$ & 18 \\
\hline 0 & $2,063,158$ & $37,136,842$ & 30.06 .2021 & 181 & $2,063,158$ & 62,239 & & $2,125,396$ & 19 \\
\hline 0 & 0 & $39,200,000$ & 31.12.2021 & 184 & $2,063,158$ & 31,635 & & $2,094,793$ & 20 \\
\hline $39,200,000$ & & & & Total & $39,200,000$ & $6,558,263$ & 588,000 & $3.38 \%$ & $I R R$ \\
\hline
\end{tabular}


Table 8 Mega metallurgy power projected balance sheet (in dollars)

\begin{tabular}{|c|c|c|c|c|c|c|c|c|c|c|}
\hline $\begin{array}{l}\text { MMP } \\
\text { balance } \\
\text { sheet (\$) }\end{array}$ & 31.12 .2012 & 31.12 .2013 & 31.12 .2014 & 31.12 .2015 & 31.12 .2016 & 31.12 .2017 & 31.12 .2018 & 31.12 .2019 & 31.12 .2020 & 31.12 .2021 \\
\hline $\begin{array}{l}\text { Accounts } \\
\text { receivable }\end{array}$ & 0 & 364,913 & 364,913 & 364,913 & 364,913 & 364,913 & 364,913 & 364,913 & 364,913 & 364,913 \\
\hline $\begin{array}{l}\text { Current } \\
\text { assets }\end{array}$ & 0 & 364,913 & 364,913 & 364,913 & 364,913 & 364,913 & 364,913 & 364,913 & 364,913 & 364,913 \\
\hline $\begin{array}{l}\text { Other fixed } \\
\text { assets }\end{array}$ & $1,111,936$ & $1,111,936$ & $1,111,936$ & $1,111,936$ & $1,111,936$ & $1,111,936$ & $1,111,936$ & $1,111,936$ & $1,111,936$ & $1,111,936$ \\
\hline Fixed assets & $56,000,000$ & $56,000,000$ & $56,000,000$ & $56,000,000$ & $56,000,000$ & $56,000,000$ & $56,000,000$ & $56,000,000$ & $56,000,000$ & $56,000,000$ \\
\hline $\begin{array}{l}\text { Accumulated } \\
\text { depreciation }\end{array}$ & $-2,911,194$ & $-5,822,387$ & $-8,733,581$ & $-1,644,774$ & $-14,555,968$ & $-17,467,162$ & $-20,378,355$ & $-23,289,549$ & $-26,200,742$ & $-29,111,936$ \\
\hline Total assets & $54,200,742$ & $51,654,461$ & $48,743,268$ & $45,832,074$ & $42,920,881$ & $40,009,687$ & $37,098,493$ & $34,187,300$ & $31,276,106$ & $28,364,913$ \\
\hline $\begin{array}{l}\text { Accounts } \\
\text { payable }\end{array}$ & 0 & 19,167 & 19,167 & 19,167 & 19,167 & 19,167 & 19,167 & 19,167 & 19,167 & 19,167 \\
\hline $\begin{array}{l}\mathrm{S} / \mathrm{T} \text { bank } \\
\text { loans }\end{array}$ & $5,216,239$ & $5,694,947$ & $5,702,792$ & $5,578,936$ & $5,350,184$ & $5,281,408$ & $5,105,176$ & $4,817,010$ & $4,412,820$ & $3,886,625$ \\
\hline $\begin{array}{l}\mathrm{L} / \mathrm{T} \text { fund } \\
\text { loans due }\end{array}$ & $4,126,316$ & $4,126,316$ & $4,126,316$ & $4,126,316$ & $4,126,316$ & $4,126,316$ & $4,126,316$ & $4,126,316$ & $4,126,316$ & 0 \\
\hline $\begin{array}{l}\text { Current } \\
\text { liabilities }\end{array}$ & $9,342,555$ & $9,840,429$ & $9,848,275$ & $9,724,418$ & $9,495,666$ & $9,426,890$ & $9,250,658$ & $8,962,493$ & $8,558,302$ & $3,905,791$ \\
\hline $\begin{array}{l}L / T \text { fund } \\
\text { loans }\end{array}$ & $33,010,526$ & $28,884,211$ & $24,757,895$ & $20,631,579$ & $16,505,263$ & $12,378,947$ & $8,252,632$ & $4,126,316$ & 0 & 0 \\
\hline L/T liabilities & $33,010,526$ & $28,884,211$ & $24,757,895$ & $20,631,579$ & $16,505,263$ & $12,378,947$ & $8,252,632$ & $4,126,316$ & 0 & 0 \\
\hline Capital & $16,800,000$ & $16,800,000$ & $16,800,000$ & $16,800,000$ & $16,800,000$ & $16,800,000$ & $16,800,000$ & $16,800,000$ & $16,800,000$ & $16,800,000$ \\
\hline $\begin{array}{l}\text { Retained } \\
\text { earnings }\end{array}$ & 0 & $-4,952,339$ & $-3,870,178$ & $-2,662,901$ & $-1,323,923$ & 119,951 & $1,403,849$ & $2,795,204$ & $4,298,492$ & $5,917,804$ \\
\hline Net income & $-4,952,339$ & $1,082,160$ & $1,207,277$ & $1,338,979$ & $1,443,874$ & $1,283,898$ & $1,391,354$ & $1,503,288$ & $1,619,312$ & $1,741,317$ \\
\hline $\begin{array}{l}\text { Total liabilities } \\
\text { and equity }\end{array}$ & $54,200,742$ & $51,654,461$ & $48,743,268$ & $45,832,074$ & $42,920,881$ & $40,009,687$ & $37,098,493$ & $34,187,300$ & $31,276,106$ & $28,364,913$ \\
\hline
\end{tabular}

the following features: automatic lubricating systems, dry-toothed belt pitch drive system, greased gear spurs ensuring fewer maintenance issues, robust cooling system, no intermediate transmission, advanced variable speed control, wide adjustable control range, better quality electrical output, advanced power controls allowing for

Table 9 Mega metallurgy power projected income table (in dollars)

\begin{tabular}{|c|c|c|c|c|c|c|c|c|c|c|}
\hline MMP income table (\$) & 2012 & 2013 & 2014 & 2015 & 2016 & 2017 & 2018 & 2019 & 2020 & 2021 \\
\hline Sales & 0 & $4,378,952$ & $4,378,952$ & $4,378,952$ & $4,378,952$ & $4,378,952$ & $4,378,952$ & $4,378,952$ & $4,378,952$ & $4,378,952$ \\
\hline $\begin{array}{l}\text { Net carbon emission } \\
\text { savings }\end{array}$ & 0 & $1,227,093$ & $1,227,093$ & $1,227,093$ & $1,227,093$ & $1,227,093$ & $1,227,093$ & $1,227,093$ & $1,227,093$ & $1,227,093$ \\
\hline Operating expense & 0 & $-230,000$ & $-230,000$ & $-230,000$ & $-230,000$ & $-230,000$ & $-230,000$ & $-230,000$ & $-230,000$ & $-230,000$ \\
\hline Overhead expense & 0 & $-50,000$ & $-50,000$ & $-50,000$ & $-50,000$ & $-50,000$ & $-50,000$ & $-50,000$ & $-50,000$ & $-50,000$ \\
\hline $\begin{array}{l}\text { Maintenance expense } \\
\text { (Goldwind) }\end{array}$ & 0 & $-100,000$ & $-100,000$ & $-100,000$ & $-100,000$ & $-100,000$ & $-100,000$ & $-100,000$ & $-100,000$ & $-100,000$ \\
\hline $\begin{array}{l}\text { Administrative and } \\
\text { operational expenses }\end{array}$ & 0 & $-30,000$ & $-30,000$ & $-30,000$ & $-30,000$ & $-30,000$ & $-30,000$ & $-30,000$ & $-30,000$ & $-30,000$ \\
\hline $\begin{array}{l}\text { All risk insurance } \\
\text { expense }\end{array}$ & 0 & $-50,000$ & $-50,000$ & $-50,000$ & $-50,000$ & $-50,000$ & $-50,000$ & $-50,000$ & $-50,000$ & $-50,000$ \\
\hline Depreciation expense & $-2,911,194$ & $-2,911,194$ & $-2,911,194$ & $-2,911,194$ & $-2,911,194$ & $-2,911,194$ & $-2,911,194$ & $-2,911,194$ & $-2,911,194$ & $-2,911,194$ \\
\hline Interest expense & $-2,041,145$ & $-1,382,691$ & $-1,257,575$ & $-1,125,873$ & $-990,990$ & $-859,979$ & $-725,659$ & $-585,742$ & $-440,711$ & $-288,205$ \\
\hline Corporate tax at $20 \%$ & 0 & 0 & 0 & 0 & $-29,988$ & $-320,975$ & $-347,839$ & $-375,822$ & $-404,828$ & $-435,329$ \\
\hline Net income & $-4,952,339$ & $1,082,160$ & $1,207,277$ & $1,338,979$ & $1,443,874$ & $1,283,898$ & $1,391,354$ & $1,503,288$ & $1,619,312$ & $1,741,317$ \\
\hline
\end{tabular}


Table 10 Mega metallurgy power valuation (in dollars)

\begin{tabular}{|c|c|c|c|c|c|c|c|c|c|c|}
\hline $\begin{array}{l}\text { MMP discounted cash flow } \\
\text { valuation }(\$)\end{array}$ & 2012 & 2013 & 2014 & 2015 & 2016 & 2017 & 2018 & 2019 & 2020 & 2021 \\
\hline$\overline{W_{e}}$ & $22 \%$ & $25 \%$ & $29 \%$ & $34 \%$ & $39 \%$ & $46 \%$ & $53 \%$ & $62 \%$ & $73 \%$ & $86 \%$ \\
\hline$W_{\mathrm{d}}$ & $78 \%$ & $75 \%$ & $71 \%$ & $66 \%$ & $61 \%$ & $54 \%$ & $47 \%$ & $38 \%$ & $27 \%$ & $14 \%$ \\
\hline$K_{\mathrm{d}}$ & $6 \%$ & $6 \%$ & $6 \%$ & $6 \%$ & $6 \%$ & $6 \%$ & $6 \%$ & $6 \%$ & $5 \%$ & $5 \%$ \\
\hline WACC & $6 \%$ & $6 \%$ & $7 \%$ & $7 \%$ & $7 \%$ & $8 \%$ & $8 \%$ & $9 \%$ & $9 \%$ & $10 \%$ \\
\hline EBITDA & 0 & $5,376,045$ & $5,376,045$ & $5,376,045$ & $5,376,045$ & $5,376,045$ & $5,376,045$ & $5,376,045$ & $5,376,045$ & $5,376,045$ \\
\hline Non-cash working capital change & 0 & $-345,746$ & 0 & 0 & 0 & 0 & 0 & 0 & 0 & 0 \\
\hline Tax & 0 & 0 & 0 & 0 & $-29,988$ & $-320,975$ & $-347,839$ & $-375,822$ & $-404,828$ & $-435,329$ \\
\hline Free cash flow & - & $5,030,299$ & $5,376,045$ & $5,376,045$ & $5,346,057$ & $5,055,071$ & $5,028,207$ & $5,000,223$ & $4,971,217$ & $4,940,716$ \\
\hline Discount factor & - & 1.06 & 1.13 & 1.21 & 1.30 & 1.39 & 1.50 & 1.63 & 1.78 & 1.96 \\
\hline Present value & - & $4,733,763$ & $4,750,119$ & $4,447,802$ & $4,128,026$ & $3,630,450$ & $3,344,706$ & $3,065,080$ & $2,790,739$ & $2,520,549$ \\
\hline Sum of present values & $21,690,159$ & & & & & & & & & \\
\hline Terminal growth rate & $1 \%$ & & & & & & & & & \\
\hline Terminal value & $78,347,787$ & & & & & & & & & \\
\hline Terminal value present value & $56,267,802$ & & & & & & & & & \\
\hline Firm value & $77,957,961$ & & & & & & & & & \\
\hline Net cash position & $-9,342,555$ & & & & & & & & & \\
\hline Discounted cash flow value & $68,615,406$ & & & & & & & & & \\
\hline
\end{tabular}

complete adjustability of total output and rate of change, increased reactive power, adjustable output power, low voltage ride through, and successful grid connection [12].

\section{Emission analysis}

Turkey's $\mathrm{CO}_{2}$ emission coefficient $\left(C_{\mathrm{TR}}\right)$, which is defined as the number of tons of $\mathrm{CO}_{2}$ emitted per gigawatt hour of energy produced, is 0.511 . This coefficient is calculated by dividing the $101,473,200$ tons of annual $\mathrm{CO}_{2}$ emissions of all power plants in the country $\left(X_{\mathrm{P} 08}\right)$ [13] by the $198,418,000 \mathrm{GW} h$ of annual electricity production of all power plants in $2008\left(E_{\mathrm{P} 08}\right)$ [14] (Equation 1):

$$
C_{T R}=\frac{X_{P 08}}{E_{P 08}}
$$

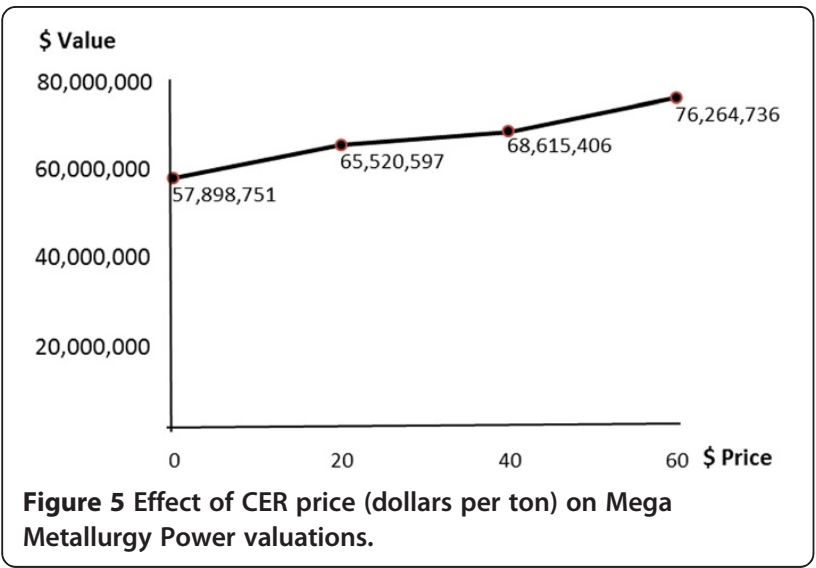

In 2008, Mega Metallurgy, with an annual production of 50,000 tons of steel $(M)$, is assumed to operate at the same $2010 \mathrm{CO}_{2}$ emission level as Isdemir [15], which is a subsidiary of Erdemir, the largest steel production company in the country. Therefore, the $\mathrm{CO}_{2}$ emission coefficient of Mega Metallurgy per crude steel production $\left(C_{\mathrm{M}}\right)$ is 2.05. The total annual $\mathrm{CO}_{2}$ emission of Mega Metallurgy $\left(X_{\mathrm{M} 08}\right)$ is calculated at 102,500 tons (Equation 2):

$$
\mathrm{X}_{\mathrm{M} 08}=\mathrm{MC}_{\mathrm{M}}
$$

Because the plant was not operational in 1990, the national steel industry $\mathrm{CO}_{2}$ emission inventory data of 9,402,020 tons $\left(X_{\mathrm{SI} 190}\right)$ for 1990 [16] and 12,769,350 tons $\left(X_{\mathrm{SI08}}\right)$ for 2008 [13] are proportioned, to find the 1990 $\mathrm{CO}_{2}$ emission of Mega Metallurgy $\left(X_{\mathrm{M} 90}\right)$, which is 75,470 tons (Equation 3):

$$
\mathrm{X}_{\mathrm{M} 90}=\frac{\mathrm{X}_{\mathrm{SI} 90} \mathrm{X}_{\mathrm{M} 08}}{\mathrm{X}_{\mathrm{SI} 08}}
$$

To comply with the Kyoto Protocol, the plant should decrease its $\mathrm{CO}_{2}$ emissions by $5.2 \%$ relative to 1990 levels. Therefore, allowed annual $\mathrm{CO}_{2}$ emission for Mega Metallurgy $\left(X_{\mathrm{MA}}\right)$ is 71,550 tons (Equation 4), and hence, the firm should make up for the excess 30,950 tons $\left(X_{\mathrm{ME}}\right)$ (Equation 5).

$$
\begin{aligned}
& \mathrm{X}_{\mathrm{MA}}=\mathrm{X}_{\mathrm{M} 90}(1-0.052) \\
& \mathrm{X}_{\mathrm{ME}}=\mathrm{X}_{\mathrm{M} 08}-\mathrm{X}_{\mathrm{MA}}
\end{aligned}
$$

Otherwise, the firm would have to buy CERs at market rate. The prices of CERs fluctuate primarily because of 
the costs of projects that generate them and supplydemand fundamentals that drive their trade on financial markets. Like energy prices, carbon prices are very sensitive to energy supply shocks. The escalating international oil price also feeds higher prices for carbon emission permits or EU allowances. Because of rising gas prices, dirtier coal becomes a more attractive fuel for EU power generators and other heavy users of fossil fuels covered by the EU ETS, such as the iron and steel industries. The price may increase further as the market digests a new emission outlook in Europe. When an entity covered by the ETS misses the deadlines for surrendering emission allowances, it runs the risk of triggering enforcement procedures. The EU ETS Directive calls for a $\$ 130$ penalty for each ton of carbon dioxide equivalent emitted, for which the operator has not surrendered allowances [17]. Phase 3 of the EU ETS could see the price of EU allowances (EUA) rise from $\$ 39 /$ ton in 2013 to $\$ 52 /$ ton in 2016. Such an increase, from current levels of around $\$ 19.5 /$ ton, is vital to meet the EU's current emission reduction targets of 20\% below 1990 levels. There are three likely scenarios. First, there is the EU-20 scenario, whereby the EU does not increase its current emission reduction target. Second, there is the EU-30 scenario, where the current reduction target is increased to 30\% below 1990 levels, and third, there is the ETS linking scenario, in which the EU ETS establishes a full link with the US ETS and other ETS schemes before 2018. The EU-20 scenario would lead to a price range of $\$ 32.5$ to $\$ 65 /$ ton by 2016 ; the EU-30 scenario, to a price range of $\$ 45.5$ to $\$ 84.5 /$ ton by 2016 ; and the final scenario, to a price range of $\$ 13$ to $\$ 39 /$ ton by 2016. The latter is significantly lower than the first two scenarios because of new and expanded crediting mechanisms and a larger import limit. In 2009, emission projections were dramatically reduced following the economic downturn, which resulted in lower emissions and a surplus of EUA and CERs in phase 2 that can be banked into phase 3. At the same time, the USA has become an active and constructive participant in international climate negotiations, and a climate agreement seems within reach. Therefore, it is now more likely that the EU will adopt a $30 \%$ reduction target. Furthermore, cap-and-trade schemes in the USA and other regions have become more likely, which increase the potential of the USA linking with the EU ETS [18].

\section{Power generation analysis}

Once an eligible location in Hatay was selected, wind velocities at the following coordinates (Table 2 ) were measured monthly for 6 years (Table 3 ) and daily (Table 4) using masts.

Then, on the basis of a Weibull distribution, the cumulative frequency of wind velocities between cut-in and cut-out limits of the turbine is calculated (Table 5).
The capacity factor $\left(C_{\mathrm{W}}\right)$ of the location is calculated at $40 \%$ (Table 6).

Wind turbine power $\left(P_{\mathrm{WW}}\right)$ is calculated using the following: $7,857 \mathrm{~m}^{2}$ as the area swept by the blades $(A)$, $1.225 \mathrm{~kg} / \mathrm{m}^{3}$ as air density at $15^{\circ} \mathrm{C}$ and normal atmospheric pressure $(\rho)$, a 0.47 turbine power coefficient $\left(C_{\mathrm{P}}\right)$, and $6.49 \mathrm{~m} / \mathrm{s}$ as wind velocity $(V)$. This calculation (Equation 6) yields a turbine power of $619 \mathrm{~kW}$ :

$$
\mathrm{P}_{\mathrm{W}}=0.5 \mathrm{C}_{\mathrm{P}} \rho \mathrm{AV}^{3}
$$

Annual capacity $(C)$ is calculated at 3,460 h (Equation 7):

$$
\mathrm{C}=8,760 \mathrm{C}_{\mathrm{W}}
$$

The annual energy $\left(E_{\mathrm{W}}\right)$ per turbine is calculated at 2,142,344 kW h (Equation 8):

$$
\mathrm{E}_{\mathrm{W}}=\mathrm{P}_{\mathrm{W}} \mathrm{C}
$$

Annual $\mathrm{CO}_{2}$ savings $(S)$ per turbine is 1,096 tons (Equation 9):

$$
\mathrm{S}=\frac{\mathrm{C}_{\mathrm{TR}} \mathrm{E}_{\mathrm{W}}}{1,000}
$$

The number of turbines required $\left(N_{\mathrm{T}}\right)$ is 28 (Equation 10), and hence, the total installed capacity $\left(P_{\mathrm{WT}}\right)$ is $70 \mathrm{MW}$ (Equation 11) with an estimated annual energy production $\left(E_{\mathrm{WT}}\right)$ of $59,985,643 \mathrm{~kW} \mathrm{~h}$ (Equation 12) and total annual $\mathrm{CO}_{2}$ savings $\left(S_{\mathrm{T}}\right)$ of 30,667 tons (Equation 13 ).

$$
\begin{aligned}
& \mathrm{N}_{\mathrm{T}}=\frac{\mathrm{X}_{\mathrm{ME}}}{\mathrm{S}} \\
& \mathrm{P}_{\mathrm{WT}}=2,5 \mathrm{~N}_{\mathrm{T}} \\
& \mathrm{E}_{\mathrm{WT}}=\mathrm{E}_{\mathrm{W}} \mathrm{N}_{\mathrm{T}} \\
& \mathrm{S}_{\mathrm{T}}=\mathrm{SN}_{\mathrm{T}}
\end{aligned}
$$

At an average CER price estimation $\left(P_{\mathrm{CER}}\right)$ of $\$ 40 /$ ton that is based on future CER price analysis, annual savings $\left(S_{\$}\right)$ for establishing this wind power plant would be $\$ 1,227,093$ (Equation 14).

$$
\mathrm{S}_{\$}=\mathrm{S}_{\mathrm{T}} \mathrm{P}_{\mathrm{CER}}
$$

\section{Financial analysis}

Twenty-eight 2.5-MW Goldwind wind turbines with an 80-m hub height cost \$56 million, which includes transportation costs, crane hiring for erection, a supervisory control and data acquisition system for remote monitoring and supervision, and aviation lights. The availability of high leverages in the local financial market for such renewable energy projects is an advantage for Mega Metallurgy. A total of $\$ 39.2$ million in long-term loan drawdowns with a 10-year term, 1-year grace period, equal principal repayments, semi-annual interest payments at an all-in cost 
interest rate of $3 \%$ with an upfront arrangement fee of $1.5 \%$, and a $70 \%$ long-term $(\mathrm{L} / \mathrm{T})$ loan/(equity $+\mathrm{L} / \mathrm{T}$ loan) ratio can be obtained from local creditors (Table 7).

For a 10-year (2012 to 2021) financial projection of Mega Metallurgy Power, interest, foreign exchange, and inflation rates are assumed constant, and cash flow deficits are financed by short-term $(\mathrm{S} / \mathrm{T})$ loans (Table 8).

Electricity sale price is taken as $7.3 \mathrm{cent} / \mathrm{kW} \mathrm{h}$, which is in line with the final draft of the Renewable Energy Law (Table 9).

Mega Metallurgy Power performance is taken as the market average; hence, its beta is 1 . To calculate the cost of debt $\left(K_{\mathrm{d}}\right)$, the cost of short- and long-term debts before tax is assumed to be the market rates of $5 \%$ and $6 \%$, respectively. When calculating an $11 \%$ cost of equity $\left(K_{\mathrm{e}}\right)$, the risk-free rate and market risk premium are taken as a $6 \%$ yield on 10-year Turkish Eurobonds and $5 \%$ according to Turkish sovereign risk, respectively. The corporate tax rate is $20 \%$, and the company distributes no dividends. Company financials are assumed to stabilize in 2017 , with $46 \%$ weight of equity $\left(W_{\mathrm{e}}\right)$ and $8 \%$ weighted average cost of capital (WACC). Finally, a discounted cash flow value of $\$ 68.6$ million for Mega Metallurgy Power is derived at a $1 \%$ terminal growth rate [19] (Table 10).

As for the sensitivity analysis, valuation is calculated for different CER prices in which the only change to company financials is stabilization years. Although the WACC of each simulation must be exactly the same to make a perfect comparison, approximations are used so that full financial years are not split. Consequently, the enterprise value is found positively correlated with the CER prices, as seen in Figure 5.

\section{Conclusions}

If the CDM, the world's largest carbon offsetting program, prevails after 2012, CER prices will continue to have a positive impact on wind energy firm valuations and related investment decisions. However, it is also concluded that in Turkey, CER prices alone would not be sufficient to justify wind energy investment. Wind velocity is still the main determining factor, as in the case of Mega Metallurgy Power. Comparing a total financing of $\$ 61.2$ million ( $\$ 16.8$ million equity $+\$ 39.2$ million long-term loan $+\$ 5.2$ million short-term loan) with enterprise value creation of $\$ 68.6$ million, Mega Metallurgy does not find this project investment appealing. Therefore, Mega Metallurgy should consider investing in a different region with wind velocity high enough to justify their investment. Besides wind velocity and CER prices, future developments in technology and electricity sale prices should also be closely monitored for changes that would have a significant effect on investment decisions.

\section{Competing interests}

The authors declare that they have no competing interests.

\section{Authors' contributions}

MT carried out the emission and power generation analysis, and RP participated in these studies. RP carried out the technology and financial analysis, and MT participated in these studies. RP drafted the manuscript and participated in the design of the study. MT conceived the study, participated in its design, and helped draft the manuscript. All authors read and approved the final manuscript.

Received: 23 April 2012 Accepted: 4 October 2012

Published: 15 October 2012

\section{References}

1. UNFCCC (2011) United Nations framework convention on climate change. http://unfccc.int Accessed 26 Dec 2011

2. Hamilton $K$, Sjardin M (2009) Fortifying the foundation: state of the voluntary carbon markets 2009. In: (ed) Ecosystem marketplace and new carbon finance. http://www.ecosystemmarketplace.com/pages/dynamic/ resources.library.page.php?page_id=7082\&section=our_publications\&eod=1. Accessed 26 Dec 2011

3. Ambrosi P, Kossoy A (2010) State and trends of the carbon market 2010. Available via the World Bank. http://web.worldbank.org/WBSITE/EXTERNAL/ TOPICS/ENVIRONMENT/EXTCARBONFINANCE/0,contentMDK:22592488 pagePK:64168445 piPK:64168309 theSitePK:4125853,00.html. Accessed 26 Dec 2011

4. TEIAS (2011) 10-Year electricity production capacity projection of Turkey (2010-2019). Turkish Electricity Transmission Company Research Planning and Coordination, http://www.emra.org.tr/index.php/electricity-market/ electricity-publishments. Accessed 26 Dec 2011

5. Yüksel I (2010) Energy production and sustainable energy policies in Turkey. Renewable Energy 35(7):1469-1476

6. Republic of Turkey Ministry of Energy and Natural Resources (2010) Wind., http://www.enerji.gov.tr/index.php?dil=en\&sf=webpages\&b=ruzgar_EN $\& b n=231 \& h n=\& n m=40717 \& i d=40734$. Accessed 26 Dec 2011

7. Kühn M (2008) A tailwind for sustainable technology. In: Bührke T, Wengenmayr R (eds) Renewable Energy - Sustainable Concepts for the Future. Wiley-VCH, Weinheim

8. Akova I (2008) Renewable energy resources. Nobel Yayın Dagitim, Istanbul

9. Akova I (2011) Development potential of wind energy in Turkey. Available via Echogeo. http://echogeo.revues.org/12457?lang=en. Accessed 10 July 2012

10. Çamdali U, Parmaksizoğlu C, Tunç M (2006) Comparison of Turkey's electrical energy consumption and production with some European countries and optimization of future electrical power supply investments in Turkey. Energy Policy 34(1):50-59

11. Fairley P (2010) Wind turbines shed their gears. Available via technology review: published by MIT. http://www.technologyreview.com/energy/25188/page1/?a=f. Accessed 26 Dec 2011

12. Goldwind Science \& Technology Co., Ltd (2010) Goldwind., http://www.goldwindglobal.com/web/index.do. Accessed 26 Dec 2011

13. UNFCCC (2010) National inventories submissions 2010 (TUR-2010-2008-v1.2. xIs/Table1s1). In: (ed) UN framework of climate change. http://unfccc.int/ files/national_reports/annex_i_ghg_inventories/national_inventories submissions/application/zip/tur-2010-crf-15april.zip. Accessed 26 Dec 2011

14. Turkish Electricity Transmission Company (2008) Annual development of installed capacity and generation in Turkey. http://www.teias.gov.tr/ TürkiyeElektrikistatistikleri/istatistik2008/13.xls. Accessed 26 Dec 2011

15. Isdemir (2010) Sustainability report. http://www.isdemir.com.tr/wps/wcm/ connect/isdemirlibrary/isdemireng/sustainability/ isdemircontentsustainabilityreport. Accessed 26 Dec 2011

16. UNFCCC (2010) National inventories submissions 2010 (TUR-2010-1990-v1.2. xIs/Table1s1). In: (ed) UN framework of climate change. http://unfccc.int/ files/national_reports/annex_i_ghg_inventories/national_inventories_ submissions/application/zip/tur-2010-crf-15april.zip. Accessed 26 Dec 2011 
17. EUR-Lex (2003) 32003L0087: EU directives 2003/87/EC and 96/61/EC http://eur-lex.europa.eu/LexUriServ/LexUriServ.do?uri=CELEX:32003L0087:EN: HTML. Accessed 26 Dec 2011

18. Renewable Energy World (2009) Carbon trading price rise predicted. http://www.renewableenergyworld.com/rea/news/article/2009/06/carbontrading-price-rise-predicted. Accessed 26 Dec 2011

19. Rosenbaum J, Pearl J (2009) Investment banking: valuation, leveraged buyouts, and mergers and acquisitions. John Wiley \& Sons, Inc, Hoboken

doi:10.1186/2192-0567-2-20

Cite this article as: Tunç and Pak: Impact of the Clean Development Mechanism on wind energy investments in Turkey. Energy, Sustainability and Society 2012 2:20

Submit your manuscript to a SpringerOpen ${ }^{\circ}$ journal and benefit from:

- Convenient online submission

- Rigorous peer review

- Immediate publication on acceptance

- Open access: articles freely available online

- High visibility within the field

- Retaining the copyright to your article 